\title{
Optimal Design and Energy Management for a Grid Connected Renewable Hybrid System (PV-HKT-GRID)
}

\author{
Paul Arévalo ${ }^{1,2 *}$, Darío Benavides ${ }^{2,3}$, Juan L. Espinoza ${ }^{2}$, and Francisco Jurado ${ }^{1}$ \\ ${ }^{1}$ Department of Electrical Engineering, University of Jaen, EPS Linares, 23009 Jaen, Spain \\ ${ }^{2}$ Department of Electrical, Electronic and Telecommunications Engineering, University of Cuenca, 010107 Cuenca, Ecuador \\ ${ }^{3}$ Department of Electrical Engineering, University of Malaga, 29016 Malaga, Spain
}

\begin{abstract}
The integration of renewable energy is transcendental for sustainable development. This article analyses a hybrid grid-connected system composed of renewable energy technologies (photovoltaichydrokinetic), where several scenarios for energy management are proposed. They include a battery system as energy storage and a system without storage but with resale fee to grid, with the aim of determining the best economic and environmental balance. The results show that, by having a (PV-HKT-GRID) system with energy storage and no resale fee to the grid, the Net Present Cost (NPC) is increased by USD \$ 132,760 and the Cost of Energy (COE) decreases $\$ 0.013 / \mathrm{kWh}$ when compared to the grid. In addition, the same hybrid system without energy storage and no resale fee to grid, presents an energy cost savings of $\$ 0.043 / \mathrm{kWh}$, and an additional cost of USD $\$ 43,630$. Finally, if a grid resale rate is included in the renewable hybrid system, then the difference is noticeable, the savings in the Cost of Energy is $\$ 0.073 / \mathrm{kWh}$ and presents a saving in the NPC of USD \$39,930. In all cases, $\mathrm{CO}_{2}$ emissions have been avoided.
\end{abstract}

\section{Introduction}

Nowadays, in the $21^{\text {st }}$ century, there are villages that are far from the grid where it is a challenge to supply them with electricity. In [1] a technical analysis was carried out for the construction of a renewable electrification project in Peru. In reference [2], a hybrid system has been analyzed in order to meet the energy needs of a village grid-connected located in eastern Iran. The results indicate that the system is technically and economically viable. These systems are viable due to the low production cost of photovoltaic panels [3]. However, batteries could be used at peak times where it is more economical to supply the load from batteries than from the grid, and at dawn, grid power could be used to recharge the storage system [4]. In [5] the optimal sizing of a PV-Wind-Battery Bank system grid-connected has been analyzed, where the customer is less grid dependent by overcoming variations in electricity prices. Software tools such as Homer and Matlab are widely used for these types of analysis [6]-[8]. Another energy source, hydrokinetic technology (HKT), is reaching increasing acceptance since its operation takes advantage of the ecological flow of a river with a minimum environmental impact [9]. Currently this type of turbines includes a converter that regulates the output always extracting the maximum usable power [10]. By combining hydrokinetic and photovoltaic technology, the annual productivity of renewable-based electricity is increased. In [11], the energy control and optimization of the size of a renewable hybrid system (HRES) has been analyzed. The result indicates that the two renewable sources are complementary and their efficiency can be increased through proper energy control [12]. Once the problem has been identified, it is necessary to perform an analysis of a grid-connected renewable system and the feasibility of using batteries as an energy storage system. The originality of the study lies in the use of hydrokinetic technology combined with PV energy within a gridconnected system. In addition, indicators such as: NPC, $\mathrm{COE}$, operation and maintenance cost, renewable penetration, $\mathrm{CO}_{2}$ emissions, purchase and sale of energy to the grid, among others, have been used to determine new behaviors about the system using Homer software. This article is organized as follows: Section 2 presents the methodology that consists of the evaluation of the demand of the site under study, as well as the analysis of renewable resources (river speed and global solar radiation). The mathematical representation of each component that makes up the system is also included. Section 3 presents the results of the study, comparing each system based on the proposed parameters, and finally the conclusions of the study are discussed in section 4.

\section{Methodology}

\subsection{Background}

The case study is carried out in a University located in the south of Ecuador, with a power load as shown in

* Corresponding author: wpac0001@ @red.ujaen.es 
Figure 1 [13]-[14]. The peak demand time is presented at 7:00 p.m. with $30 \mathrm{~kW}$ and the minimum demand at dawn with $10 \mathrm{~kW}$ as shown in Fig. 1 [12]-[14].

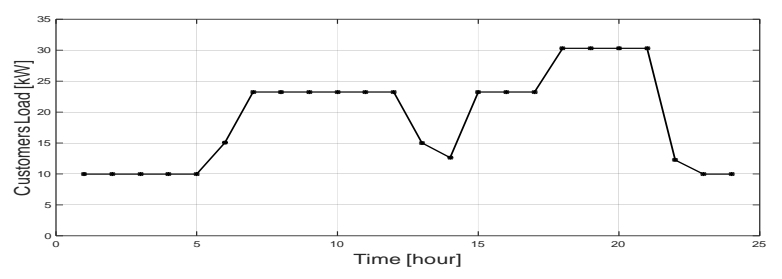

Fig. 1. Daily demand profile in $\mathrm{kW}$

The solar irradiance at the site is shown in Fig. 2. Since the site is located in Ecuador the annual radiation is approximately constant [12]-[14].

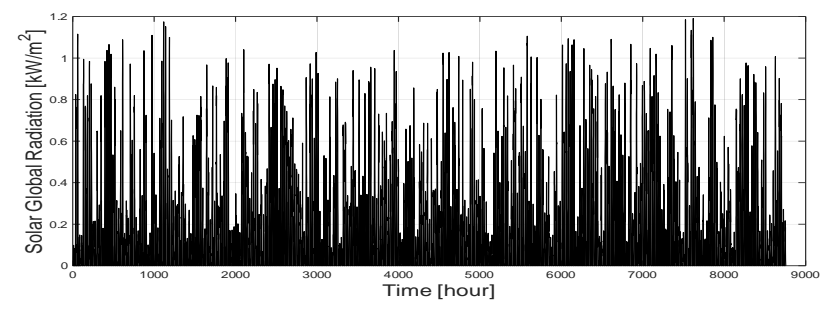

Fig. 2. Annual Solar radiation in $\mathrm{kW} / \mathrm{m}^{2}$

Regarding the water resource, it is observed in Fig. 3 that there are periods of dryness during the months of July and August. The rest of the months present a regular behavior, and in some days, there are peaks of $5.5 \mathrm{~m} / \mathrm{s}$ due to the high rainfall of the place.

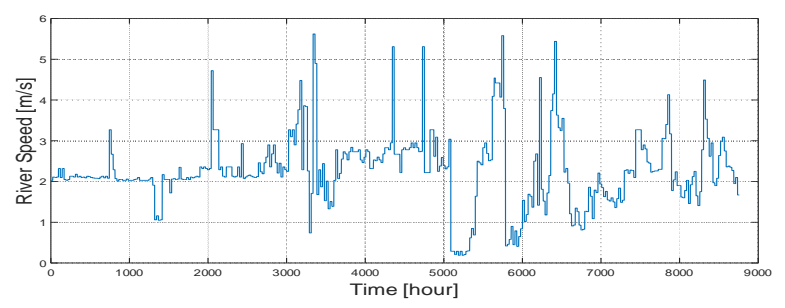

Fig. 3. River speed in $\mathrm{m} / \mathrm{s}$

\subsection{Mathematical modeling}

\subsubsection{PV System}

The PV system is made up of a set of cells, which are generally represented by equation (1), [15].

$$
P_{P V}=P_{S T C} * f_{p v}\left(\frac{G_{H R}}{G_{S T C}}\right) *\left[1+k *\left(T_{c}-T_{a}\right)\right]
$$

Where: $P_{P V}$, is the PV power output, $P_{S T C}$, is the power in standard conditions (GSTC $=1000 \mathrm{~W} / \mathrm{m}^{2}$ and 25 $\left.{ }^{\circ} \mathrm{C}\right), G_{H R}$, is the global incident radiation; $G_{S T C}$, is the incident radiation under standard conditions, $T_{c}$, is the cell temperature; $T_{a}$, room temperature; $k$ and $f_{p v}$, are the coefficient of temperature and degradation respectively of the solar panels. Table 1 presents the details of the PV modules that have been chosen for the place, of $285 \mathrm{Wp}$ and an efficiency at standard conditions of $17.40 \%$ [12].

Table 1. PV generator parameters

\begin{tabular}{|c|c|}
\hline \multicolumn{2}{|c|}{ PV Parameters } \\
\hline Pmax at STC & $285 \mathrm{~W}$ \\
\hline Capital Cost & USD $\$ 295 / 285 \mathrm{Wp}$ \\
\hline Replacement Cost & USD $\$ 290 / 285 \mathrm{Wp}$ \\
\hline Temperature coefficient & $-0.35 \% /{ }^{\circ} \mathrm{C}$ \\
\hline Lifetime & 25 years \\
\hline
\end{tabular}

\subsubsection{HKT System}

Hydrokinetic turbines can be placed in an artificial channel or in a river directly [16]. The Homer program uses the data entered to calculate the electrical power generated by the HKT [17], and is given by equation (2) [18].

$$
P_{h}=\rho * A_{T} * \frac{V_{T}^{3}}{2} * C_{p} * \eta_{G} * N_{T}
$$

Where: $V_{T}$ is section flow rate in $\mathrm{m} / \mathrm{s} ; A_{T}$ is Area of passage through the turbine rotor in $\mathrm{m}^{2} ; C_{p}$ is power coefficient is $0.3 ; \eta_{G}$ is efficiency of the electric generator (adopted as 90\%) and $N_{T}$ is the number of HKT per cross section, the parameters of the HKT are presented in Table 2 [12].

Table 2. HKT generator parameters

\begin{tabular}{|c|c|}
\hline \multicolumn{2}{|c|}{ HKT Parameters } \\
\hline Model & Smart Monofloat \\
\hline Capital Cost & USD \$ 9,000 \\
\hline Replacement Cost & USD \$ 9,000 \\
\hline O\&M Cost & USD \$ 100 \\
\hline
\end{tabular}

\subsubsection{Energy Storage System}

The SOC value is recommended to remain from $40 \%$ to $100 \%$ for guaranteeing the life of lead acid batteries. Equations (3) and (4) show the state of charge and the capacity of the batteries at time $\mathrm{t}$ [19].

$$
\operatorname{SOC}\left(t_{i}\right)=\frac{1}{C\left(t_{i}\right)} * \int_{-\infty}^{t_{i}} \eta_{c}(t) * I(t) * \partial t
$$

Where:

$C\left(t_{i}\right)$, is the capacity of the battery in amp-hours, $\eta_{c}$ $(t)$ is the charging efficiency, $I(t)$ is the current flowing through the battery.

$$
C\left(t_{i}\right)=\frac{C_{\text {nominal }} * C_{\text {tcoef }}}{1+A \operatorname{cap}\left(\frac{\mid I(t) /}{I_{\text {nominal }}}\right)^{B_{\text {cap }}}} *\left[1+\alpha_{c} * \Delta T(t)+\beta * \Delta T(t)^{2}\right]
$$

$C_{\text {nominal }}$, is the estimated capacity of the battery, $C_{\text {tcoef }}$, $A_{\text {cap }}$ and $B_{\text {cap }}$; they are parameters of the battery model, $\Delta T$ is the variation of the temperature with respect to the reference of $25{ }^{\circ} \mathrm{C}, I_{\text {nominal }}$ is the discharge current corresponding to the nominal capacity, $\alpha$ and $\beta$ are the 
temperature coefficients. The battery current is calculated by equation (5) [5].

$$
I_{b a t}(t)=\frac{P_{P V}(t)+P_{h}(t)-P_{\text {load }}(t)}{V}
$$

Where: $P_{\text {load }}$ represents the power of the load and $V$ the battery voltage. The characteristics of the selected lead acid battery are shown in Table 3 .

Table 3. Battery parameters

\begin{tabular}{|l|r|}
\hline \multicolumn{2}{|c|}{ Lead Acid Battery Parameters } \\
\hline Nominal Capacity & $1 \mathrm{kWh}$ \\
\hline Capital Cost & USD \$ 300 \\
\hline Replacement Cost & USD \$ 300 \\
\hline O\&M Cost & USD 10 \$/yr \\
\hline
\end{tabular}

\subsection{Cost analysis}

A way to evaluate a project economically is through the NPC in (\$), since it represents the current cost of the project at the end of its useful life. The COE in $(\$ / \mathrm{kWh})$ indicates the price to be paid by users for each $\mathrm{kWh}$ consumed. In this article, the NPC, COE and rescue costs are analysed as they implicitly represent the other indicators mentioned above [11], [20]. The total annualized cost $\left(C_{t a}\right)$ is calculated using equation (6) [11], [20].

$$
C_{t a}=C_{c a p}+C_{r e p}+C_{O \& M}
$$

Where: $\mathrm{C}_{\text {cap }}$ represents the investment cost or capital cost, $\mathrm{C}_{\text {rep }}$ the replacement cost of the system components and $\mathrm{C}_{(\mathrm{O} \& \mathrm{M})}$ is the maintenance operation cost. The capital recovery factor (CRF) is calculated with equation (7) [11], [20].

$$
C R F(i, n)=\frac{i^{*}(1+i)^{n}}{(1+i)^{n}-1}
$$

Where: $n$ represents the years of useful life of the project, $i$ is the annual interest rate calculated with equation (8) [11], [20].

$$
i=\frac{i^{\prime}-f}{1+f}
$$

Where $: i^{\prime}$ represents the nominal interest rate and $f$ is the annual inflation rate. Therefore, the $N P C$ is given by equation (9) [11], [20].

$$
N P C=\frac{C_{t a}}{C R F(i, n)}
$$

In addition, the Cost of Energy is calculated with equation (10), [11], [20].

$$
C O E=\frac{C_{t a}}{E_{s}}
$$

Where: $E_{s}$ is the total energy served in a year. The cost of energy purchased from the grid $\left(C_{b u y, g r i d}\right)$ is represented as follows:

$$
C_{\text {buy, grid }}=L E_{p} *\left(C O E_{\text {grid }} * P_{\text {shortage }}\right)
$$

Where: $L E_{p}$ represents the life expectancy of the project, $C O E_{\text {grid }}$ is the cost of energy purchased from the grid in $(\$ / \mathrm{kWh})$ and $P_{\text {shortage }}$ is the power shortage. The load profile is similar to the residential load, the COE in grid is $\$ 0.09 / \mathrm{kWh}$ [21], which remains constant throughout the day.

\subsection{Energy Control}

\subsubsection{First Case}

The grid has been considered as the backup system and the excess electricity of the project is sold to the grid. The total power of HRES is calculated with equation (12).

$$
P_{\text {Total, HRES }}= \begin{cases}P_{P V}+P_{h} & (a) \\ P_{P V}+P_{h}+P_{\text {grid }} & (b)\end{cases}
$$

If the renewable power is enough to meet the demand, it is supplied from the PV and HKT generator, the excess energy is sold to the grid. If the renewable power is not enough to meet the demand, energy is purchased from the grid.

\subsubsection{Second case}

The grid and the battery system are considered as backup. The load cycle energy control has been used, so if the renewable power is not enough to supply the demand, energy must be purchased from the grid, see equation (14). The priority here is to recharge the batteries in low demand hours, at peak hours the demand must be supplied from the storage system and not from the grid.

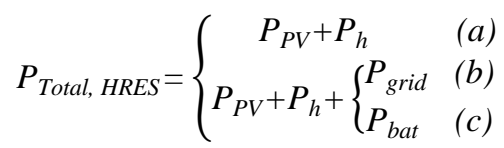

If the renewable power is enough to meet the demand, energy is supplied from the PV and HKT generator, the excess energy is sold to the grid. If the renewable power is not enough to meet the demand, energy is purchased from the grid. If the renewable power is not enough to meet the demand, the demand is supplied from the battery bank, if $\mathrm{SOC}>\mathrm{SOC}_{\min }$. The third case is the same, it only includes resale to the grid

\section{Results}

Figure 4 shows the result of the conditions raised. It is evident that at hour 85 the state of charge of the batteries is approximately $45 \%$, the demand is $15 \mathrm{~kW}$ and the total renewable power $(\mathrm{PV}+\mathrm{HKT})$ is $23 \mathrm{~kW}$. In this moment, renewable production decreases gradually and demand on the contrary grows, the state of charge of the batteries is the minimum and the cost of $\mathrm{kWh}$ is low, so it is convenient to buy energy from the grid to recharge the 
batteries and supply part of the demand to ensure an enough SOC. The main objective of this scheme is to maintain high levels of reliability and quality of electricity supply.

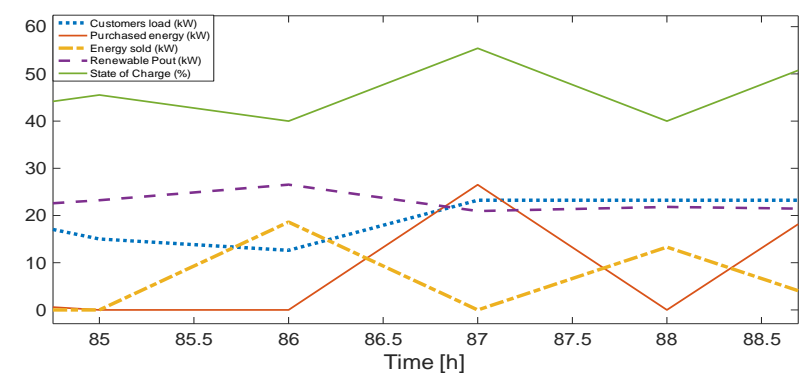

Fig. 4. Energy control under random conditions

The comparison of different alternatives has been performed. Table 4 shows the simulation results.

Table 4. Results of simulation

\begin{tabular}{|c|c|c|c|c|}
\hline Parameters & $1^{\text {st }}$ Case & $2^{\text {nd }}$ Case & $3^{\text {rd }}$ Case & Grid \\
\hline PV & $50 \mathrm{~kW}$ & $50 \mathrm{~kW}$ & $50 \mathrm{~kW}$ & - \\
\hline HKT & 10 units & 10 units & 10 units & - \\
\hline AC/DC & $66 \mathrm{~kW}$ & $36 \mathrm{~kW}$ & $40 \mathrm{~kW}$ & - \\
\hline LAB capacity & $120 \mathrm{kWh}$ & - & - & - \\
\hline NPC system & $\$ 258,930$ & $\$ 170,340$ & $\$ 86,780$ & $\$ 126,710$ \\
\hline COE system & $\begin{array}{c}0.08 \\
\$ / \mathrm{kWh}\end{array}$ & $\begin{array}{c}0.05 \\
\$ / k W h\end{array}$ & $\begin{array}{c}0.02 \\
\$ / \mathrm{kWh}\end{array}$ & $\begin{array}{l}0.093 \\
\$ / \mathrm{kWh}\end{array}$ \\
\hline Rescue (\$) & $-9,848$ & $-5,145$ & $-5,145$ & - \\
\hline PV & $20.74 \%$ & $20.81 \%$ & $20.81 \%$ & - \\
\hline HKT & $70.24 \%$ & $70.45 \%$ & $70.45 \%$ & - \\
\hline $\begin{array}{c}\text { Grid } \\
\text { purchases }\end{array}$ & $9.22 \%$ & $8.74 \%$ & $8.74 \%$ & $100 \%$ \\
\hline Grid sales & $57.34 \%$ & $57.46 \%$ & $57.46 \%$ & - \\
\hline $\begin{array}{c}\mathrm{CO}_{2} \\
\text { emissions }\end{array}$ & $\begin{array}{l}-82,855 \\
\mathrm{~kg} / \text { year }\end{array}$ & $\begin{array}{l}-76,855 \\
\mathrm{~kg} / \text { year }\end{array}$ & $\begin{array}{l}-76,855 \\
\mathrm{~kg} / \text { year }\end{array}$ & $\begin{array}{c}67,361 \\
\mathrm{~kg} / \text { year }\end{array}$ \\
\hline
\end{tabular}

In the first case (On grid + Battery), a grid-connected renewable system with batteries, the COE is $0.08 \$ / \mathrm{kWh}$ and the NPC of $\$ 258,930$. This system has an expense with respect to purchasing energy from the grid, it is USD \$ 132,760 and a saving in the COE of $0.013 \$ / \mathrm{kWh}$. However, HRES has avoided $82,855 \mathrm{~kg} /$ year of $\mathrm{CO}_{2}$ emissions. In this case there is no payment for resale of energy to the grid. In the second alternative (On grid without Battery and resale fee), since the batteries are not available, the system is cheaper because there is no resale fee to the grid. In this case the savings in the COE is $0.043 \$ / \mathrm{kWh}$, with an additional expense of NPC $=$ USD $\$ 43,630$. Moreover, a saving of $76,855 \mathrm{~kg} /$ year of $\mathrm{CO}_{2}$ emissions. The third case is like the first, the difference lies in the existence of an energy resale rate from HRES to the grid. According to [21] the cost per $\mathrm{kWh}$ of a hydroelectric plant of less than $10 \mathrm{MW}$ is $\$ 0.0207 / \mathrm{kWh}$ and $\$ 0.118 / \mathrm{kWh}$ for photovoltaic installations. Since a real price for HKT technology has not been defined, the price of the hydroelectric plant has been used due to its similarity. Since it is a HRES, for the simulation an average value of $\$ 0.069 / \mathrm{kWh}$ was used. It is worth mentioning that, in Ecuador the regulation [21] has been repealed by [22]. At this time it is not clear the situation of tariffs for renewable energy in the country in 2019 , so the values of [21] have been used. In this case, the difference is remarkable, the savings in the COE is $\$$ $0.073 / \mathrm{kWh}$ and also presents a savings in the NPC of USD \$ 39,930. In addition, the emission of 67,361 $\mathrm{kg} /$ year of $\mathrm{CO} 2$ has been avoided.

\section{Conclusions}

The use of renewable sources to supply the energy demand requires the development of new design methods of grid connected HRES, and the possibility of adding storage systems to take advantage of the variation in electricity prices and reduce emissions. The proposed energy management has shown that, when electricity is produced using an HRES composed of PV/HKT without a resale fee to the grid, it is more expensive than buying power directly from the grid in terms of NPC. This is because in the national interconnected electric system of Ecuador, the cost of $\mathrm{kWh}$ is relatively cheap and constant during the day. However, having a basic resale rate, the system is cheaper than the grid. Nevertheless, without an energy storage system and no resale fee to the grid, there is an energy cost savings of $\$ 0.043 / \mathrm{kWh}$, an additional cost of USD $\$ 43,630$. Finally, if a grid resale rate is included in the renewable hybrid system, the difference is notable, the COE savings are $\$ 0.073 / \mathrm{kWh}$ and it also presents a savings in the NPC of USD $\$ 39,930$. In addition, in all the proposed systems, the COE is cheaper compared to the grid with a very important additional aspect, such as avoiding tons of $\mathrm{CO}_{2}$ emissions into the atmosphere. Further, it increases the reliability of the system by having more sources of generation and adding a positive economic term consisting of the possibility of selling excess energy to the grid. In future studies, those analyzes should be covered. Additionally, different energy storage technologies must be studied to have a clearer impact on HRES.

We thank the Research Department of the University of Cuenca (DIUC), for the support provided in this article

\section{References}

1. B. Domenech, L. Ferrer-Martí, P. Lillo, R. Pastor, and J. Chiroque, "A community electrification project: Combination of microgrids and household systems fed by wind, PV or micro-hydro energies according to micro-scale resource evaluation and social constraints," Energy Sustain. Dev., vol. 23, pp. 275-285, (Dec. 2014).

2. A. Kasaeian, P. Rahdan, M. A. V. Rad, and W. M. Yan, "Optimal design and technical analysis of a grid-connected hybrid photovoltaic/diesel/biogas under different economic conditions: A case study," Energy Convers. Manag., vol. 198, (Oct. 2019).

3. M. H. Jahangir, S. A. Mousavi, and M. A. Vaziri $\mathrm{Rad}$, "A techno-economic comparison of a photovoltaic/thermal organic Rankine cycle with 
several renewable hybrid systems for a residential area in Rayen, Iran," Energy Convers. Manag., vol. 195, pp. 244-261, (Sep. 2019).

4. A. Chakir et al., "Optimal energy management for a grid connected PV-battery system," in Energy Reports, (2019).

5. A. Kamjo, A. Maheri, G. Putrus, A. Disqah., "Optimal sizing of grid-connected hybrid wind-pv systems with battery bank storage." Conference: World Renewable Energy Forum (WERF), (January-2012):

6. F. A. Khan, N. Pal, and S. H. Saeed, "Review of solar photovoltaic and wind hybrid energy systems for sizing strategies optimization techniques and cost analysis methodologies," Renewable and Sustainable Energy Reviews, vol. 92. Elsevier Ltd, pp. 937-947, (01-Sep-2018).

7. A. Maleki and A. Askarzadeh, "Artificial bee swarm optimization for optimum sizing of a stand-alone PV/WT/FC hybrid system considering LPSP concept," Sol. Energy, vol. 107, pp. 227-235, (2014).

8. A. Maleki and F. Pourfayaz, "Optimal sizing of autonomous hybrid photovoltaic/wind/battery power system with LPSP technology by using evolutionary algorithms," Sol. Energy, vol. 115, pp. 471-483, May (2015).

9. F. Wamalwa, S. M. Sichilalu, and X. Xia, "Optimal energy mix of a microhydro-wind-grid system powering a dairy farm in Western Cape, South Africa.," in Energy Procedia, (2017), vol. 142, pp. 708-715.

10. E. Alvarez Alvarez, M. Rico-Secades, E. L. Corominas, N. Huerta-Medina, and J. Soler Guitart, "Design and control strategies for a modular hydroKinetic smart grid," Int. J. Electr. Power Energy Syst., vol. 95, pp. 137-145, (Feb. 2018).

11. P. Arévalo, D. Benavides, J. Lata-García, and F. Jurado, "Energy Control and Size Optimization of a Hybrid System (Photovoltaic-Hidrokinetic) Using Various Storage Technologies," Sustain. Cities Soc., p. 101773, (Aug. 2019).

12. J. Lata-García, F. Jurado, L. M. Fernández-Ramírez, and H. Sánchez-Sainz, "Optimal hydrokinetic turbine location and techno-economic analysis of a hybrid system based on photovoltaic/hydrokinetic/hydrogen/battery," Energy, vol. 159, pp. 611-620, (Sep. 2018).

13. P. Arévalo, D. Benavides, and F. Jurado "Energy Control and sizing optimization of an off grid Hybrid System (Wind-Hydrokinetic-Diesel)"
Colombian Conference on Automatic Control IEEE (IEEE-CCAC).

14. P. Arévalo, D. Benavides, Juan Espinoza, Luis Hernández, and F. Jurado "Impact on a microgrid using different storage systems under three energy dispatch control", Ibero-American Congress of Smart Cities (ICSC-CITIES 2019), (to be published)

15. O. Djelailia, M. S. Kelaiaia, H. Labar, S. Necaibia, and F. Merad, "Energy hybridization photovoltaic/diesel generator/pump storage hydroelectric management based on online optimal fuel consumption per $k W h$," Sustain. Cities Soc., vol. 44, pp. 1-15, (Jan. 2019).

16. M. Badrul Salleh, N. M. Kamaruddin, and Z. Mohamed-Kassim, "Savonius hydrokinetic turbines for a sustainable river-based energy extraction: A review of the technology and potential applications in Malaysia," Sustain. Energy Technol.

Assessments, vol. 36, (Dec. 2019).

17. K. Kusakana and H. J. Vermaak, "Cost and performance evaluation of hydrokinetic-diesel hybrid systems," in Energy Procedia, (2014), vol. 61, pp. 2439-2442.

18. I. F. S. dos Santos, R. G. R. Camacho, G. L. Tiago Filho, A. C. B. Botan, and B. A. Vinent, "Energy potential and economic analysis of hydrokinetic turbines implementation in rivers: An approach using numerical predictions (CFD) and experimental data," Renew. Energy, vol. 143, pp. 648-662, (Dec. 2019).

19. D. Guasch Murillo, S. Silvestre Berges, and Universitat Politècnica de Catalunya. Departament d'Enginyeria Electrònica., "Modelado y análisis de sistemas fotovoltáicos," (2003).

20. B. K. Das and F. Zaman, "Performance analysis of a PV/Diesel hybrid system for a remote area in Bangladesh: Effects of dispatch strategies, batteries, and generator selection," Energy, vol. 169, pp. 263276, (Feb. 2019).

21. Agencia de Regulación y Control de Electricidad (ARCONEL), "Pliego tarifario para las empresas eléctricas de distribución codificado servicio público de energía eléctrica." (Periodo: EneroDiciembre 2019).

22. Agencia de Regulación y Control de Electricidad (ARCONEL), "Derogatoria-CodificacionRegulacion-001-13-generadores-energia, resolución 031/16" (Enero 2019). 